\title{
Intratumoral delivery of recombinant vaccinia virus encoding for ErbB2/Neu inhibits the growth of salivary gland carcinoma cells
}

Laura Masuelli ${ }^{1}$, Massimo Fantini ${ }^{2}$, Monica Benvenuto ${ }^{2}$, Pamela Sacchetti ${ }^{1}$, Maria Gabriella Giganti ${ }^{2}$, llaria Tresoldi ${ }^{2}$, Paolo Lido ${ }^{3}$, Florigio Lista ${ }^{4}$, Federica Cavallo ${ }^{5}$, Patrizia Nanni ${ }^{6}$, Jeffrey Schlom${ }^{7}$, Andrea Modesti ${ }^{2}$ and Roberto Bei ${ }^{2 *}$

\begin{abstract}
Background: The antitumor activity induced by intratumoral vaccination with poxvirus expressing a tumor antigen was shown to be superior to that induced by subcutaneous vaccination. Salivary gland carcinomas overexpress ErbB2. Trastuzumab, a monoclonal antibody to ErbB2, was proposed for salivary gland tumors treatment. We explored the effectiveness of intratumoral vaccination with the recombinant vaccinia virus ErbB2/Neu (rV-neuT) vaccine in hampering the growth of transplanted Neu-overexpressing BALB-neuT salivary gland cancer cells (SALTO) in BALB-neuT mice.
\end{abstract}

Methods: BALB-neuT male mice were subcutaneously injected with SALTO tumor cells and intratumorally vaccinated twice with different doses of either rV-neuT or V-wt (wild-type). Tumors were measured weekly. The presence of anti-ErbB2/Neu antibodies was assayed by ELISA, immunoprecipitation or indirect immunofluorescence. Biological activity of immune sera was investigated by analyzing antibody-dependent cellular cytotoxicity (ADCC), SALTO cells proliferation and apoptosis, ErbB2/Neu receptor down regulation and ERK1/2 phosphorylation. Anti-Neu T cell immunity was investigated by determining the release of IL-2 and IFN-gamma in T cells supernatant. Survival curves were determined using the Kaplan-Meier method and compared using the log-rank test. Differences in tumor volumes, number of apoptotic cells, titer of the serum, percentage of ADCC were evaluated through a two-tailed Student's t-test.

Results: rV-neuT intratumoral vaccination was able to inhibit the growth of SALTO cancer cells in a dose-dependent manner. The anti-Neu serum titer paralleled in vivo antitumor activity of rV-neuT vaccinated mice. rV-neuT immune serum was able to mediate ADCC, inhibition of SALTO cells proliferation, down regulation of the ErbB2/Neu receptor, inhibition of ERK1/2 phosphorylation and induction of apoptosis, thus suggesting potential mechanisms of in vivo tumor growth interference. In addition, spleen T cells of rV-neuT vaccinated mice released IFN-gamma and IL-2 upon in vitro stimulation with several Neu-specific peptides located in the extracellular domain of Neu sequence.

Conclusions: rV-neuT intratumoral vaccination could be employed to induce an efficient antitumor response and reject transplanted salivary gland tumors. Our findings may have important implications for the design of cancer vaccine protocols for the treatment of salivary gland tumors and other accessible tumors using intratumoral injection of recombinant vaccinia virus.

Keywords: Vaccine, Cancer, Salivary glands, ErbB2/Neu, Vaccinia virus, Intratumor

\footnotetext{
*Correspondence: bei@med.uniroma2.it

${ }^{2}$ Department of Clinical Sciences and Translational Medicine, University of Rome "Tor Vergata", Rome, Italy

Full list of author information is available at the end of the article
} 


\section{Background}

The hallmark of poxviruses utilization in anti-cancer immunotherapy is their ability to express large foreign genes without significant disruption of the viral genome. This feature offers the possibility of expressing complex eukaryotic sequences or multiple genes in permissive mammalian cells, ensuring correct post-translational modifications [1]. To date, different poxviridae genera have been successfully used as tumor associated antigens vectors in experimental models. Engineered attenuated recombinant vaccinia virus has now been widely employed as a cancer vaccine in a large number of clinical trials as well. The results of these trials demonstrated that recombinant vaccinia virus infection upon vaccination was safe and that a specific humoral or $\mathrm{T}$ cell response against the foreign inserted tumor-associated antigen could be induced in several cancer patients [2-13]. Vaccination with recombinant vaccinia virus can be achieved by systemic (subcutaneous, intradermal, or intramuscular) or intratumoral injection [2,4-18]. Recently, it was demonstrated that the antitumor activity induced by intratumoral vaccination with an avipox virus expressing carcinoembryonic antigen (CEA) and multiple co-stimulatory molecules was superior to that induced by subcutaneous vaccination in CEA-transgenic mice [19]. Similarly, we reported that the intramammary gland vaccination with the recombinant vaccinia virus neu (rV-neuT) vaccine was more effective than the subcutaneous vaccination in inhibiting mammary carcinogenesis in BALB-neuT mice [20]. In addition, the intramammary delivery was more effective than the subcutaneous vaccination in eliciting anti-Neu antibodies, increasing anti-Neu IgG2a/G3 isotypes and inducing antibodies able to trigger mammary tumor cells apoptosis and antibody-dependent cellular cytotoxicity [20]. A prerequisite to using intratumoral delivery is the easy access for antigen delivery to the tumor site. Salivary gland tumors as well as head and neck tumors including tongue, floor of the mouth, palate and mandibular mucosa and so on, appear suitable for such vaccine delivery. Salivary gland tumors are a group of heterogeneous lesions which express ErbB2, whose current treatment involves surgery and adjuvant radio(chemo) therapy. However, therapy response rates have been generally poor for these tumors [21]. Recently, given that the high histopatological similarity between salivary ductal and breast carcinomas, Trastuzumab, a humanized monoclonal antibody to ErbB2, has been proposed as a potential therapy for salivary gland tumors treatment. However, active immunization targeting ErbB2 might induce tumor growth inhibition more efficiently than passive immunotherapy based on the generation of an extended memory immune response.

In this study we examined the effectiveness of the rV$n e u T$ intratumoral vaccination in hampering the growth of transplanted Neu-overexpressing BALB-neuT salivary gland cancer cells $\left(\mathrm{H}-2^{\mathrm{d}}\right)$ (SALTO) in BALB-neuT mice. In addition, we explored whether the efficiency of vaccination was dependent on the dose of the $\mathrm{rV}$-neuT vaccine $\left(10^{8}\right.$ vs $10^{7}$ vs $10^{6} \mathrm{pfu}$ ). Considering previous demonstration that a potent anti-Neu humoral response is required to prevent mammary tumor growth in BALB-neuT vaccinated mice, we investigated the anti-Neu humoral response following $\mathrm{rV}$-neuT vaccination as well as the in vitro biological activity of immune sera from rV-neuT vaccinated mice. Finally, we determined whether $\mathrm{rV}$-neu $\mathrm{T}$ vaccination elicits anti-Neu $\mathrm{T}$ cell immunity.

Our research suggests that intratumoral vaccination using recombinant vaccinia virus could be efficiently employed for the treatment of salivary gland tumors and other accessible tumors.

\section{Methods}

Antibodies, peptides, reagents and cells

Neu-overexpressing salivary gland cancer cells $\left(\mathrm{H}-2^{\mathrm{d}}\right)$ (SALTO) were kindly provided by Prof. Federica Cavallo (University of Turin) and maintained in DMEM containing $20 \%$ fetal bovine serum (FBS). SALTO cells were established from salivary carcinoma arising in BALB-neuT transgenic male mice hemizygous for $\mathrm{p} 53^{172 \mathrm{R}-\mathrm{H}}$ transgene driven by the whey acidic protein promoter [22,23]. NIH3T3 cells expressing normal rat Neu (LTR-Neu) have been previously characterized and kindly provided by Dr. Eddi Di Marco (Tumor Institute of Genova) [24]. Renal epithelial cell lines BSC-1 and NIH3T3 cells were purchased by ATCC. BSC-1, LTR-Neu and NIH3T3 were maintained in DMEM containing 10\% FBS. Monoclonal antibody anti-Neu Ab4 (PC04) was purchased from Oncogene Science (Cambridge, MA, USA). Rabbit polyclonal anti-Neu antibody (C18), anti-ERK1/2 antibody and monoclonal antibody anti pERK1/2 were purchased by Santa Cruz Biotechnology (Dallas, Texas, USA). Rabbit polyclonal antibody recognizing the activated cleaved caspase-3 was purchased from Cell Signaling Technology (Beverly, MA, USA).

Goat anti-mouse IgG Alexa fluor-488-conjugated antibody and goat anti-rabbit IgG Alexa fluor-594-conjugated antibody were purchased from Life Technologies ${ }^{\mathrm{TM}}$ Molecular Probes (Oregon, USA). Protein G-sepharose, sulforhodamine $\mathrm{B}$, Concanavalin $\mathrm{A}$, goat anti-rabbit secondary antibody HRP-conjugated and all the chemicals were purchased by Sigma Aldrich (Milan, IT). Synthetic peptides located in the extracellular (Neu 15.3, aa 66-74; Neu 42, aa 169-183; Neu 98, aa 393-407; Neu 141, aa 566-580; Neu 156, aa 626-640), transmembrane (Neu 166, aa 666-680) domains of rat Neu sequence [NCI, PubMed Accession 1202344A] [25] were previously described [26].

\section{Poxviruses}

The recombinant vaccinia virus encoding the neu oncogene was designated rV-neuT (vT67RR-1-1, original lot 
from Therion Biologics Corp: \#SC012197). It encodes the full-length activated rat neu oncogene [NCI, PubMed Accession 1202344A] [25]. The wild-type control vaccinia virus was designated V-wt (original lot from Therion Biologics Corp: \#062797-NYCBH). Therion Biologics Corp. (Cambridge, MA, USA) kindly provided the poxviruses [20].

Expression of recombinant NeuT encoded by rV-neuT was detected by Western blotting after infection of BSC-1 or NIH3T3 cells with V-wt or rV-neuT. Cells were infected with $10 \mathrm{pfu}$ (plaque forming unit)/cell of poxviruses and cultured at $37^{\circ} \mathrm{C}$ for $18 \mathrm{~h}$. Cell lysates, protein concentrations and immunoblotting were performed as previously described [27]. Polyclonal anti-ErbB2/Neu antibody was used to detect recombinant NeuT.

\section{Transgenic BALB-neuT mouse colony}

Transgenic BALB-neuT male mice were routinely mated with BALB/c females ( $\mathrm{H}-2^{\mathrm{d}}$; Charles River, Calco, Italy) in the animal facilities of Tor Vergata University. Progenies were confirmed for presence of the transgene by Polymerase Chain Reaction (PCR) [28]. Mice were bred under pathogen-free conditions and handled in compliance with European Union and institutional standards for animal research.

\section{Recombinant vaccinia neu vaccination protocol}

The protocol of vaccination was approved by the Ethical Committee of the University of Rome "Tor Vergata" and submitted to the Italian Health Department.

Six to 8 weeks old BALB-neuT male mice were subcutaneously injected in the right flank with $0.2 \mathrm{ml}$ suspension containing $1 \times 10^{6}$ SALTO cells in phosphate-buffered saline (PBS). When mice presented a palpable tumor mass around $300 \mathrm{~mm}^{3}$ (mean tumor volume 281-356 $\mathrm{mm}^{3}$ ), were intratumorally vaccinated with either $\mathrm{rV}$-neuT or $\mathrm{V}$ wt and boosted two weeks later.

Viruses were diluted in PBS such that the dose was delivered in $100 \mu \mathrm{l}$. Mice were immunized twice. BALB$n e u T$ received for each vaccination a dose of $10^{8} \mathrm{pfu}$ of either rV-neuT (n. 9 mice) or V-wt (n. 9 mice), a dose of $10^{7}$ pfu of either rV-neuT (n. 8 mice) or V-wt (n. 6 mice) and a dose of $10^{6} \mathrm{pfu}$ of either rV-neuT (n. 6 mice) or V-wt (n. 6 mice).

\section{Analysis of antitumor activity in vivo}

Tumor growth was monitored weekly until tumor-bearing mice were sacrificed when tumor exceeded $20 \mathrm{~mm}$ diameter. Tumors were measured by a calliper in two dimensions and the volumes were calculated using the formula: width $^{2} \times$ length/2 [29].

\section{Antibody immunity following vaccination with rV-neuT} Sera from vaccinated BALB-neuT mice were collected prior to vaccination and 7 days after the final boost. The presence of antibodies reactive to p185 Neu was assayed using NIH3T3, LTR-Neu and SALTO cells by enzymelinked immunosorbent assay (ELISA) or immunoprecipitation following western blotting as previously described [30-32]. For ELISA, individual rV-neuT mouse serum at different dilutions $(1: 1000,1: 2500,1: 12500)$ was assayed against LTR-Neu and NIH3T3 control $\left(5 \times 10^{4}\right.$ cells/well). The specific absorbance of each sample was calculated by subtracting LTR-Neu absorbance from that of NIH3T3 cells. Antibody titer was estimated as the highest immune serum dilution generating a specific absorbance of 0.5 at $492 \mathrm{~nm}$. Sera titer is the mean value of individual serum titers [33]. Individual serum samples from mice receiving $\mathrm{rV}$-neuT were randomly chosen. Individual $\mathrm{V}$-wt mouse serum was assayed at 1:250 dilution. Immunoglobulin subclasses were determined by ELISA using a Mouse Typer Isotyping Kit (Bio-Rad, Richmond, CA, USA) using individual serum of $\mathrm{rV}$-neuT vaccinated mice as previously described [29,33].

For immunoprecipitation, cells were lysed in RIPA buffer containing $1 \%$ Triton $\mathrm{X}-100,0.5 \%$ deoxicolate, $0.1 \%$ SDS, $20 \mathrm{mM}$ Tris $\mathrm{pH}$ 7.5, $150 \mathrm{mM}$ sodium chloride, proteases and phosphatases inhibitors. Protein concentration was determined using the Bradford protein assay (Bio-Rad, Richmond, CA, USA). Equal amounts of total proteins were immunoprecipitated using sera derived from different animals immunized with rV-neuT or V-wt, and Protein Gsepharose overnight at $4^{\circ} \mathrm{C}$. The immunoprecipitates were washed three times with RIPA buffer, boiled at $95^{\circ} \mathrm{C}$ and centrifuged to remove sepharose beads. The immunoprecipitates were separated by SDS-PAGE and transferred into nitrocellulose membrane [30]. After blocking with 5\% nonfat milk, the membrane was incubated with polyclonal antineu antibody C18 (Santa Cruz Biotechnology Inc. Dallas, Texas, USA). After washing, the membranes were incubated with goat anti-rabbit secondary antibody HRPconjugated. The antigen-antibody binding was visualized by chemiluminescence using SuperSignal West Pico Chemiluminescent Substrate kit (Pierce, IL, USA) [34].

\section{Biologic activity of vaccinated mouse immune sera in vitro}

Antibody-dependent cellular cytotoxicity (ADCC) was investigated as previously described [26,35]. BALB-neuT SALTO tumor cells $\left(5 \times 10^{3}\right.$ cells/well) were used as targets, while spleen cells from normal BALB/c mice were used as effectors at 50:1. Dilutions $(1: 10,1: 20,1: 40)$ of sera pooled from four mice vaccinated with $10^{8}$ pfu rV-neuT or V-wt were assayed. Percentage of specific lysis was calculated as described [36]. The results represent average percentage of cytotoxicity of two independent experiments. Four randomly chosen serum samples were pooled each time and used for two independent experiments. 
For cell proliferation of BALB-neuT SALTO tumor cells, immunoglobulins (Igs) from $10^{8} \mathrm{rV}$-neuT and $\mathrm{V}$-wt pooled sera were purified by protein $\mathrm{G}$ and dialyzed against PBS. Purity was determined by SDS-PAGE and Coomassie blue staining. SALTO cells $\left(2.5 \times 10^{4}\right.$ cells/well $)$ were incubated in serum-free DMEM containing $0.2 \%$ BSA containing Igs (20 or $10 \mu \mathrm{g} / \mathrm{ml}$ ). Igs were replenished every $24 \mathrm{~h}$. All treatments were performed in triplicate. Survival of cells was assessed by the Sulforhodamine B cell proliferation assay [37]. The percent change in relative cell number was calculated as described by Yip et al. [38].

To analyze the ability of serum antibodies to induce down regulation of ErbB2/Neu receptor on SALTO tumor cells, indirect immunofluorescence under native conditions was performed. Briefly, cells were detached by incubation with $0.02 \%$ EDTA in PBS and incubated with purified Igs derived from $\mathrm{rV}$-neuT or $\mathrm{V}$-wt vaccinated mice at $4^{\circ} \mathrm{C}$ for 2 hours. After washes with cold PBS, cells were labelled with goat anti-mouse IgG Alexa fluor-488-conjugated antibody (Life Technologies ${ }^{\mathrm{TM}}$ Molecular Probes, Oregon, USA) for 1 hour on ice, washed and immediately observed with an Olympus BX51 microscope; I.A.S. version 007000 Deconvolution $2 \mathrm{D}$ software was used to deconvolve $\mathrm{z}$ series images of stained native cells [39]. To analyze the ability of Igs to induce receptor down regulation, SALTO tumors cells were incubated in complete medium for 1 hour at $37^{\circ} \mathrm{C}$ in a $\mathrm{CO}_{2}$ incubator after immunolabeling with Igs from $\mathrm{rV}$-neuT or $\mathrm{V}$-wt vaccinated mice and goat antimouse-fluorescent antibody. SALTO cells were then observed and analyzed as above.

For western blotting analysis of ERK1/2, $40 \mu \mathrm{g}$ of V-wt or $\mathrm{rV}$-neuT Igs chronically treated (see above) SALTO cell lysates were separated by SDS-PAGE and processed for western blotting as previously described using anti-ERK1/ 2 and anti-pERK1/2 specific antibodies [37,40]. The intensity of the bands obtained in two independent experiments was quantified using the Image J software after blot scanning, and densitometric ratios between the phosphorylated and total levels of each protein were calculated.

For detection of programmed cell death, SALTO cells $\left(2.5 \times 10^{4}\right.$ cells/well $)$ were incubated in serum-free DMEM containing $0.2 \%$ BSA containing Igs $(10 \mu \mathrm{g} / \mathrm{ml})$ from $\mathrm{rV}$ neuT or $\mathrm{V}$-wt vaccinated mice for 72 hours. Igs were replenished every $24 \mathrm{~h}$. Cells were fixed in $4 \%$ formaldehyde for $15 \mathrm{~min}$ and after washing they were incubated with the polyclonal anti-activated caspase- 3 antibody for $1 \mathrm{~h}$. After washing, cells were labelled with goat anti-rabbit IgG Alexa fluor-594-conjugated antibody (Life Technologies ${ }^{\mathrm{TM}}$ Molecular Probes, Oregon, USA) for $60 \mathrm{~min}$ [26]. After washing, cells were incubated with $0.1 \mu \mathrm{g} / \mathrm{ml}$ Hoechst 33342 and mounted under a coverslip in glycerol. Staurosporine at $1 \mu \mathrm{M}$ incubated for $24 \mathrm{~h}$ was used as positive control. The percentage of apoptotic cells was calculated by determining the activated caspase- 3 positive cells/total cells evaluating five randomly chosen microscopic fields. Count of apoptotic cells was done in a blinded fashion.

\section{IL-2 and IFN- $\gamma$ release assay}

Spleen cells from BALB-neuT vaccinated mice were harvested 7 days after the final vaccination as previously described [26]. Spleen mononuclear cells $\left(2 \times 10^{6} /\right.$ well in 24-well plates) were incubated with Concanavalin A (ConA, $2 \mu \mathrm{g} / \mathrm{ml})$, several Neu peptides $(10 \mu \mathrm{g} / \mathrm{ml})$ or a control gag peptide. Neu peptides were selected based on immunoreactivity in vitro with lymphocytes from BALB-neuT mice vaccinated with recombinant adenovirus, LTR-Neu and rV-neuT $[20,26,41]$. IL-2 and IFN- $\gamma$ release into the supernatant was measured using an enzymatic immunocapture assay (Quantikine, R\&D Systems, Minneapolis, MN, USA).

\section{Statistical analysis}

Mean and standard deviation describes continuous variables. Survival curves were determined using the Kaplan-Meier method and compared by the log-rank test (Mantel-Cox). Differences in tumor volumes, number of apoptotic cells, titer of the serum, percentage of ADCC, intensity of immunoreactive bands were evaluated by a two-tailed Student's t-test. Statistical associations were considered significant at $\mathrm{p}$-values $\leq 0.05$.

\section{Results}

\section{Expression of recombinant NeuT encoded by rV-neuT}

Expression of recombinant NeuT encoded by rV-neuT was detected by Western blotting after $\mathrm{rV}$-neuT infection of BSC-1 and NIH3T3 cells. As shown in Figure 1, polyclonal anti-HER-2/neu antibody detected a $185 \mathrm{kDa}$

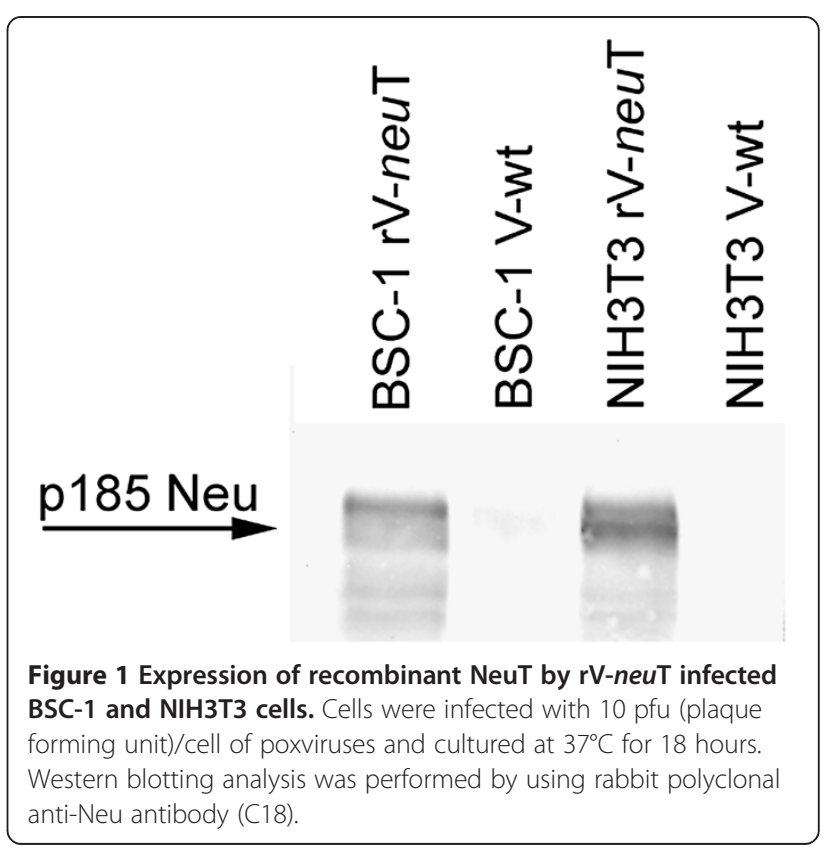


protein product on $\mathrm{rV}$-neuT-infected BSC-1 and NIH3T3 cells but not in V-wt-infected cells.

\section{Inhibition of tumor growth by recombinant vaccinia neu (rV-neuT) vaccine}

To determine whether the vaccination with rV-neuT was able to induce inhibition of the growth of transplanted p185 Neu positive tumor (SALTO) and whether it was dependent on $\mathrm{rV}$-neuT doses, BALB-neuT male mice were challenged in the right flank with $1 \times 10^{6}$ SALTO cells, and immunized twice intratumorally with three different doses of $\mathrm{rV}$-neuT or $\mathrm{V}$-wt $\left(10^{8}, 10^{7}, 10^{6} \mathrm{pfu}\right)$. Vaccinations were performed at two weeks interval.

Vaccination with $\mathrm{rV}$-neuT at the dose of $10^{8}$ pfu was able to induce regression of transplanted tumors (Figure 2), and to elicit an immunological memory that protected mice against a second injection of SALTO cells (data not shown). When considering the effectiveness of the $\mathrm{rV}$-neu $\mathrm{T}$ vaccine independently of dose, the mean survival time of mice vaccinated with $\mathrm{rV}$-neuT versus those receiving the $\mathrm{V}$-wt was 14.8 versus 2.63 weeks $(\mathrm{p}<0.0001)$ (Figure 2, Panel B).

The $10^{8}$ pfu dose vaccination was started when mean tumor volume was $307 \mathrm{~mm}^{3}$ (9 mice) and $321 \mathrm{~mm}^{3}$ (9 mice) in $\mathrm{rV}$-neuT or $\mathrm{V}$-wt vaccinated-mice, respectively. Two weeks after the first vaccination mean tumor volume of $\mathrm{V}$-wt vaccinated mice reached $3351 \mathrm{~mm}^{3}$ while mean tumor volume of $\mathrm{rV}$-neuT vaccinated mice was $123 \mathrm{~mm}^{3}$ $(\mathrm{p}<0.001)$ (Figure 2, Panel A). At this stage $1 / 9 \mathrm{rV}$-neuT vaccinated mice was tumor free. One mouse of this group died for unknown reason although the tumor volume was diminishing after the first vaccination. Four weeks after the first vaccination $5 / 9 \mathrm{rV}$-neuT vaccinated mice were tumor free and two weeks later $8 / 9 \mathrm{rV}$-neuT vaccinated mice were tumor free and remained in this status until the $30^{\text {th }}$ week. Conversely, all V-wt vaccinated mice were sacrificed for exceeded tumor volume or spontaneously died at the third week after the first vaccination $(\mathrm{p}<0.001)$ (Figure 2 , Panel $\mathrm{C})$. Overall, the mean survival time of mice vaccinated with $10^{8} \mathrm{pfu} \mathrm{rV}$-neuT versus those receiving the $10^{8} \mathrm{pfu} \mathrm{V}$-wt dose was 27 versus 2.25 weeks ( $<0.0001$ ) (Figure 2 , Panel $C$ ).

The $10^{7} \mathrm{pfu}$ dose vaccination was started when mean tumor volume was $356 \mathrm{~mm}^{3}$ (8 mice) and $332 \mathrm{~mm}^{3}$ (6 mice) for $\mathrm{rV}$-neuT and $\mathrm{V}$-wt vaccinated mice, respectively. Three weeks after the first vaccination mean tumors volume was $1052 \mathrm{~mm}^{3}$ and $4319 \mathrm{~mm}^{3}$ in $\mathrm{rV}$-neuT e $\mathrm{V}$-wt vaccinated mice, respectively $(\mathrm{p}<0.001)$ (Figure 2 , Panel A). Four mice vaccinated with rV-neuT were sacrificed four weeks after the first vaccination for exceeded tumor size and one mouse died, while all V-wt vaccinated mice were sacrificed within the fourth week after the first vaccination $(\mathrm{p}<0.001)$. Only $2 / 8$ mice of the $\mathrm{rV}$-neuT vaccinated group were still alive at the $7^{\text {th }}$ week but they were sacrificed within the $8^{\text {th }}$ week (Figure 2, Panel C). The mean survival time of mice vaccinated with $10^{7}$ pfu rVneuT versus those receiving the $10^{7}$ pfu $\mathrm{V}$-wt dose was 5.25 versus 3 weeks $(\mathrm{p}=0.0003$ ) (Figure 2, Panel $\mathrm{C}$ ).

Finally, the $10^{6}$ pfu dose vaccination was started when mean tumor volume was $281 \mathrm{~mm}^{3}$ (6 mice) and $298 \mathrm{~mm}^{3}$

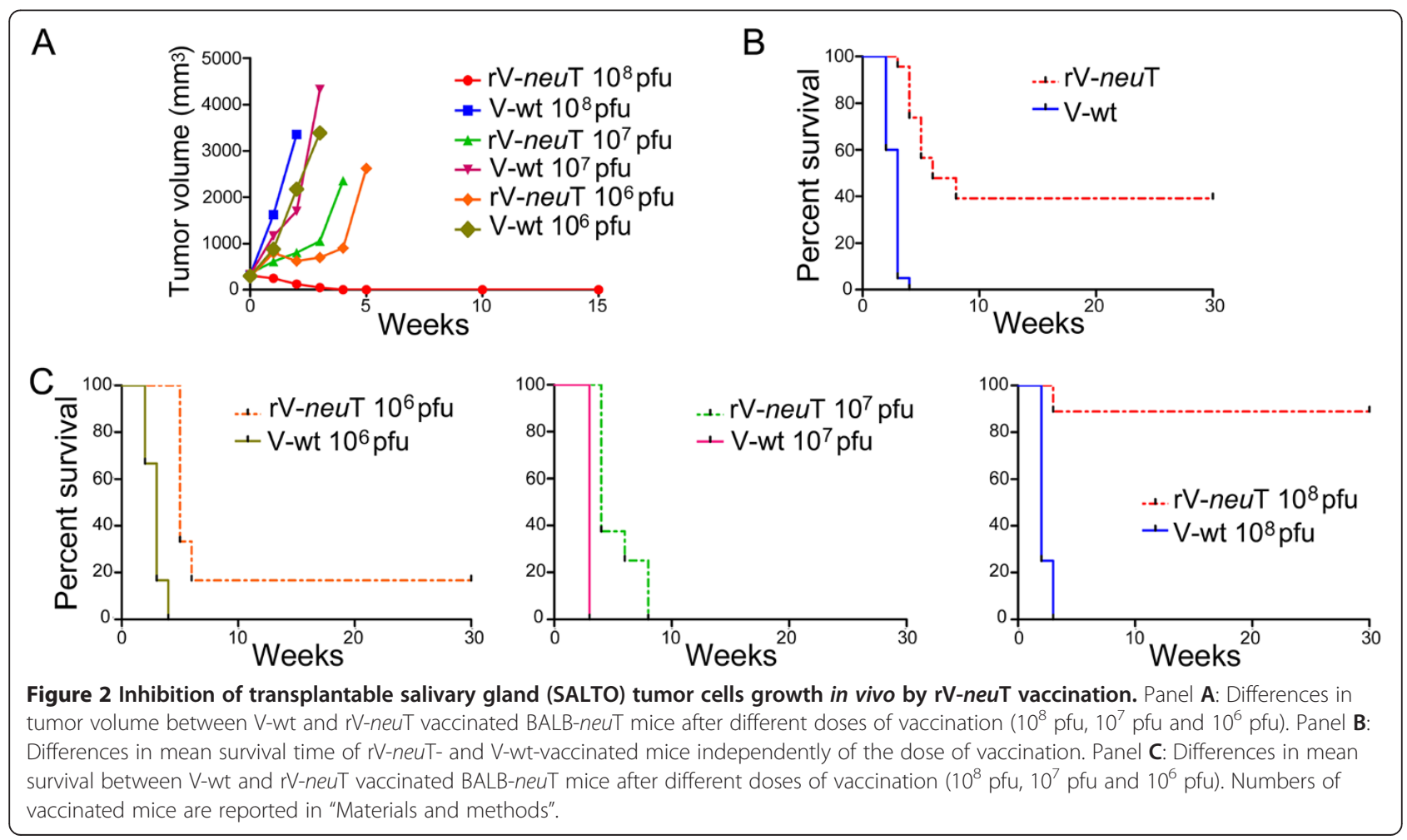


(6 mice) for $\mathrm{rV}$-neuT and $\mathrm{V}$-wt, respectively. Two weeks after the first vaccination mean tumor volume was $624 \mathrm{~mm}^{3}$ and $2167 \mathrm{~mm}^{3}$ in the group of mice vaccinated with $\mathrm{rV}$-neuT and V-wt, respectively $(\mathrm{p}=0.0096)$ (Figure 2, Panel A). Two out of six mice vaccinated with $\mathrm{V}$-wt were sacrificed at this stage. At the third week after vaccination 3/6 V-wt vaccinated mice were sacrificed while 1/6 rV$n e u T$ vaccinated mice was tumor free (mean tumor volume: 3385 vs $699 \mathrm{~mm}^{3}$ for the vaccination with V-wt and $\mathrm{rV}$-neuT, respectively; $\mathrm{p}=0.0009$ ). Only $1 / 6$ mice of the group vaccinated with $\mathrm{V}$-wt was alive four weeks after the first vaccination. Conversely $6 / 6 \mathrm{rV}$-neuT vaccinated mice (mean tumor size: $901 \mathrm{~mm}^{3}$ ) were alive at this stage. At the $7^{\text {th }}$ week, only $1 / 6 \mathrm{rV}$-neuT vaccinated mice was alive and remained tumor free until the $30^{\text {th }}$ week (Figure 2, Panel C). The mean survival time of mice vaccinated with $10^{6} \mathrm{pfu} \mathrm{rV}$-neuT versus those receiving the $10^{6} \mathrm{pfu} \mathrm{V-wt}$ dose was 9.33 versus 2.83 weeks $(\mathrm{p}=0.0006)$ (Figure 2, Panel C).

Overall, when comparing the survival of BALB-neuT mice upon vaccination it was observed that the risk of growth of SALTO tumor cells in the rV-neuT vaccinated group was 0.04 in comparison to $\mathrm{V}$-wt vaccinated group. In addition, the dose of the vaccine significantly affected mice survival (Table 1). The risk of developing tumors in the $10^{6}$ pfu and $10^{7}$ pfu rV-neuT vaccinated groups was 10.26 and 14.05 in comparison to the $10^{8} \mathrm{pfu} \mathrm{rV}$-neuT vaccinated group (Table 1). No difference was found between the $10^{7}$ and $10^{6}$ pfu rV-neuT vaccination.

These results suggest that $\mathrm{rV}$-neuT intratumoral vaccination is able to induce inhibition of the growth of transplanted salivary gland Neu positive tumor cells and that the effect of vaccination is dose-dependent. The lower doses $\left(10^{6}\right.$ e and $\left.10^{7} \mathrm{pfu}\right)$ were able to induce in $\mathrm{rV}$-neuT vaccinated mice only a delay in SALTO tumor cells growth as compared to $\mathrm{V}$-wt vaccinated mice. In this regard, the mean survival time of mice vaccinated with $10^{8} \mathrm{pfu} \mathrm{rV}$ neuT versus those receiving the $10^{7} \mathrm{pfu} \mathrm{rV}$-neuT and $10^{6}$ pfu $\mathrm{rV}$-neuT doses was 27 versus 5.25 weeks $(\mathrm{p}=0.0007)$ and $9.33(\mathrm{p}=0.012)$ weeks, respectively (Figure 2, Panel C).
Anti-Neu humoral response following rV-neuT vaccination Previous studies reported that anti-Neu humoral response is required to inhibit mammary tumor growth in BALB$n e u T$ vaccinated mice [35]. Antibody response to p185 Neu was quantitatively and qualitatively evaluated by immunoprecipitation following western blotting, ELISA and immunofluorescence in order to determine whether differences in humoral response existed between rV-neuT or Vwt administration before and after vaccination.

Specific anti-Neu reactivity in sera from rV-neuT vaccinated mice was visualized by immunoprecipitation followed by western blotting by using an anti-Neu specific antibody, and LTR-Neu and SALTO cells as antigen source.

The expression of p185 Neu in LTR-Neu and in SALTO cells was analyzed by western blotting. As shown in Figure 3, Panel A, NIH3T3 fibroblasts did not express p185 Neu, while LTR-Neu and SALTO cells showed high levels of expression of p185 Neu. Specific antibody response to Neu was qualitatively evaluated by indirect immunofluorescence and immunoprecipitation analysis. Mouse pre-immune or immune sera were collected prior to vaccination or one week after the final boost. SALTO cells were incubated with purified Igs derived from $\mathrm{rV}$-neuT or $\mathrm{V}$-wt BALB-neuT vaccinated mice followed by labeling with goat anti-mouse IgG Alexa fluor-488-conjugated antibody. Figure 3, Panel B shows representative membrane staining of SALTO cells by Igs form rV-neuT vaccinated mice similarly to that of monoclonal anti-Neu antibody Ab4. Conversely, Igs derived from V-wt vaccinated Balb-neuT mice or pre immune serum (data not shown) did not bind SALTO cells. Sera were employed to immunoprecipitate p185 Neu from LTR-Neu or SALTO cells. Specific reactivity was visualized by immunoblotting of immunoprecipitates using a Neu-specific commercial antibody (C18). Analysis of serum reactivity taken from representative $10^{8} \mathrm{pfu} \mathrm{rV}$-neuT and $\mathrm{V}$-wt vaccinated mice is depicted in Figure 3, Panel C. rV-neuT vaccination was able to induce specific anti-Neu antibodies able to immunoprecipitate the antigen from LTR-Neu and SALTO cells. Specific antibodies were detected in all $\mathrm{rV}$-neuT vaccinated mice.

Table 1 Comparison of BALB-neuT mice survival after rV-neuT and V-wt vaccination by log-rank (Mantel-Cox) test

\begin{tabular}{|c|c|c|c|c|c|}
\hline \multirow[t]{2}{*}{ Variable } & \multirow[t]{2}{*}{ Contrast } & \multirow[t]{2}{*}{ Hazard ratio } & \multicolumn{2}{|c|}{$95 \%$ hazard ratio confidence limits } & \multirow[t]{2}{*}{$p$ value } \\
\hline & & & Lower & Upper & \\
\hline \multirow[t]{4}{*}{ Vaccine } & rV-neuT vs V-wt & 0.04 & 0.014 & 0.11 & $<0.0001$ \\
\hline & rV-neuT $10^{8}$ pfu vs V-wt $10^{8}$ pfu & 0.035 & 0.007 & 0.19 & $<0.0001$ \\
\hline & rV-neuT $10^{7}$ pfu vs V-wt $10^{7} \mathrm{pfu}$ & 0.022 & 0.003 & 0.18 & 0.0003 \\
\hline & rV-neuT $10^{6}$ pfu vs V-wt $10^{6}$ pfu & 0.04 & 0.006 & 0.25 & 0.0006 \\
\hline \multirow[t]{3}{*}{ Dose } & rV-neuT $10^{7}$ pfu vs rV-neuT $10^{8}$ pfu & 14.05 & 3.05 & 64.66 & 0.0007 \\
\hline & rV-neuT $10^{6}$ pfu vs rV-neuT $10^{8} \mathrm{pfu}$ & 10.26 & 1.65 & 63.63 & 0.012 \\
\hline & rV-neuT $10^{6}$ pfu vs rV-neuT $10^{7}$ pfu & & & & NS \\
\hline
\end{tabular}




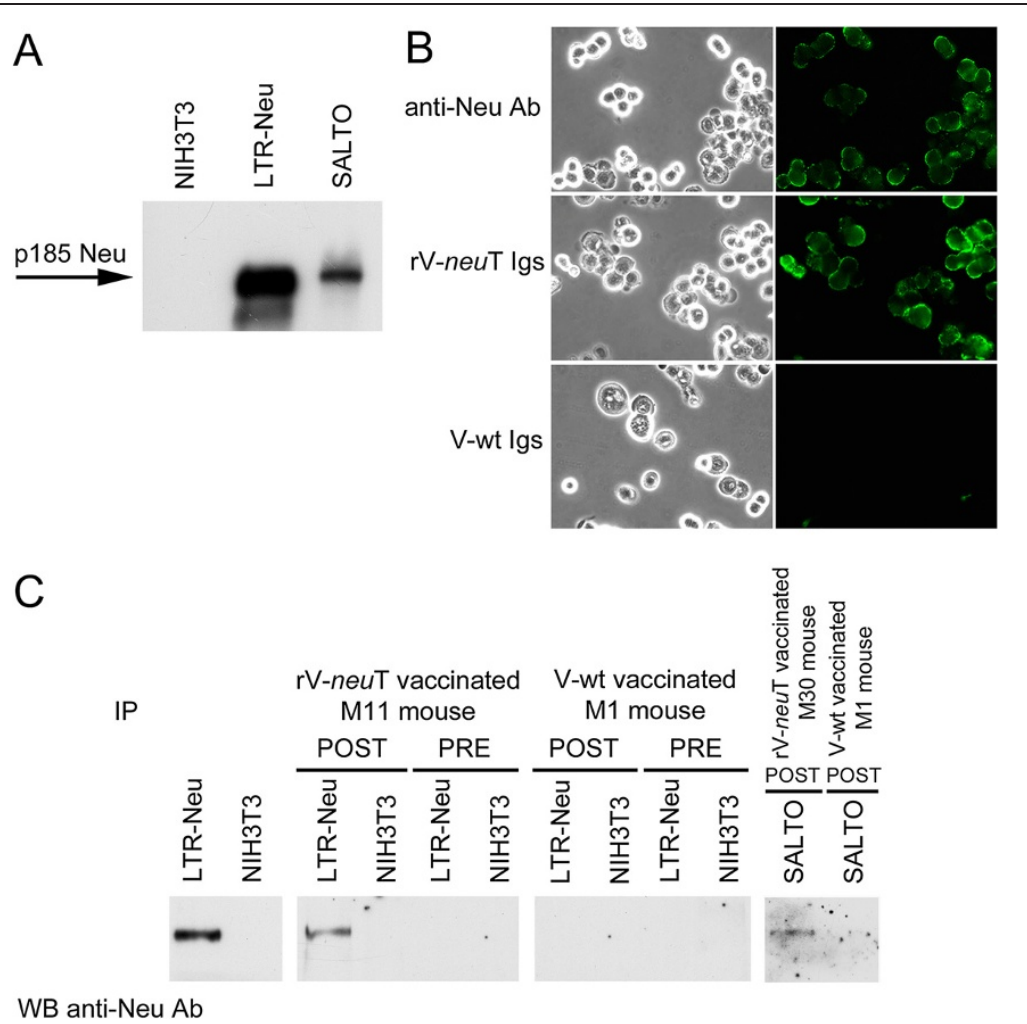

Figure 3 Anti-Neu humoral response following rV-neuT vaccination. Panel A: p185 Neu expression in NIH3T3 cells encoding normal rat Neu (LTR-Neu) and in Neu-overexpressing BALB-neuT salivary gland cancer (SALTO) cells by western blotting. A specific polyclonal anti-Neu (C18) antibody was used. NIH3T3 cells were used as negative control. Panel B: Igs from rV-neuT vaccinated mice recognize p185 Neu expressed on the surface of SALTO tumor cells. Immunofluorescence was performed using purified lgs $(1 \mu \mathrm{g} / \mathrm{ml})$ of BALB-neuT mice vaccinated with $\mathrm{rV}$-neuT or V-wt. The specific monoclonal antibody anti-Neu Ab4 was used as positive control. Olympus BX51 microscope and I.A.S. version 007000 Deconvolution 2D software were used to deconvolve z series images of stained native cells. Original magnification x400. Panel C: Serum antibody response of mice upon vaccination with rV-neuT. Numbering identifies immune sera of individual mice. Mouse pre-immune or immune sera were collected prior to vaccination or one week after the second immunization and employed in immunoprecipitation of Neu from LTR-Neu or SALTO tumor cells. p185 Neu specificity was visualized by immunoblotting analysis using receptor-specific polyclonal antibody of immunoprecipitates and compared to direct immunoblotting of LTR-Neu lysate as positive control, or NIH3T3 as negative control.

Conversely, serum from V-wt vaccinated mice was not able to immunoprecipitate the antigen from LTR-Neu.

Specific antibody response to $\mathrm{Neu}$ was quantitatively evaluated by ELISA. As shown in Table 2, $10^{8}$ pfu rV-neuT vaccinated mice developed a significantly higher titer of anti-Neu antibodies than $10^{7}$ pfu rV-neuT and $10^{6}$ pfu rV$n e u T$ vaccinated mice. No significant difference on antiNeu titer antibodies was observed between the $10^{7} \mathrm{pfu}$ $\mathrm{rV}$-neuT and $10^{6} \mathrm{pfu} \mathrm{rV}$-neuT dose. It is of note that antiNeu serum titer paralleled antitumor in vivo activity of $\mathrm{rV}$-neuT vaccinated mice. The administration of $\mathrm{V}$-wt did not result in the induction of anti-Neu antibodies.

Experiments were then carried out to evaluate the isotype of the immunoglobulins (Igs) elicited by $\mathrm{rV}$-neuT vaccination. As shown in Table 3, anti-Neu-immunoglobulins of $\mathrm{rV}$-neuT vaccinated Balb-neuT mice were mainly of the IgG1 (32\%), IgG2a (22\%) and IgG2b (16\%) isotype with a lesser amount of IgG3, IgM and IgA.
Table 2 Immunoreactivity of rV-neuT vaccinated BALB-neuT mouse sera with Neu

\begin{tabular}{|c|c|c|c|}
\hline $\begin{array}{l}\text { Dose of } \\
\text { rV-neuT }\end{array}$ & $\begin{array}{l}\text { Number of mice } \\
\text { with immune } \\
\text { response/total }\end{array}$ & $\begin{array}{l}\text { Number of } \\
\text { pooled sera }\end{array}$ & $\begin{array}{l}\text { Serum } \\
\text { titer }(S D)^{b}\end{array}$ \\
\hline $10^{8} \mathrm{pfu}$ & $8 / 8$ & 5 & $\begin{array}{c}11875^{c}(1250) p=0.000288^{d} \\
p=0.0045^{e}\end{array}$ \\
\hline $10^{7} \mathrm{pfu}$ & $4 / 4$ & 4 & 1950 (1706) \\
\hline $10^{6} \mathrm{pfu}$ & $6 / 6$ & 5 & 3380 (3750) \\
\hline
\end{tabular}

${ }^{\mathrm{a}}$ Immune response was determined by ELISA against LTR-Neu and NIH3T3. Optical density (O.D) of V-wt sera at 1:250 to LTR-Neu was $\leq 0.3$. These values were considered negative. Values for rV-neuT serum was considered positive when specific O.D value was $\geq 0.5$ at the $1: 1000$ dilution.

${ }^{\mathrm{b}}$ Immune sera titers of BALB-neuT vaccinated mice were determined by ELISA against LTR-Neu and NIH3T3 using individual serum at different dilutions $(1: 1000,1: 2500,1: 12500)$. Sera titer represents the mean value of individual serum titer \pm standard deviation (SD).

'Titer was estimated as the highest immune serum dilution generating a specific absorbance of 0.5 at $492 \mathrm{~nm}$.

$\mathrm{d}^{8} 10^{8}$ pfu vs $10^{7}$ pfu.

e $10^{8}$ pfu vs $10^{6}$ pfu. 
Table 3 Anti-neu-immunoglobulins isotype of rV-neuT vaccinated BALB-neuT mice

\begin{tabular}{|c|c|c|c|c|c|}
\hline \multicolumn{6}{|c|}{ Immunoglubulins isotype against $\mathrm{Neu}$} \\
\hline $\lg \mathrm{g} 1$ & $\operatorname{lgG} 2 a$ & $\operatorname{lgG} 2 b$ & $\operatorname{lgG3}$ & $\lg M$ & $\lg A$ \\
\hline $32.52 \pm 7.37^{a}$ & $22.28 \pm 5.43$ & $16.65 \pm 5.54$ & $11.5 \pm 1.9$ & $11.15 \pm 1.78$ & $5.87 \pm 0.8$ \\
\hline
\end{tabular}

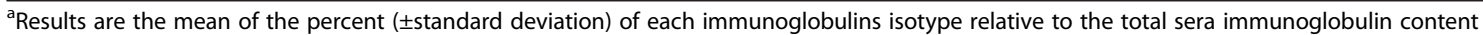
(at 1:1500) of $10^{8}$ pfu rV-neuT vaccinated mice.

\section{In vitro biological activity of immune sera of rV-neuT vaccinated mice}

ADCC, cell proliferation of BALB-neuT SALTO tumor cells, receptor down regulation and induction of apoptosis in SALTO cells were analyzed using pooled sera or purified Igs from $10^{8} \mathrm{pfu} \mathrm{rV}$-neuT or $\mathrm{V}$-wt vaccinated mice in order to investigate potential mechanisms of tumor inhibition by anti-Neu Igs. As shown in Figure 4, Panel A, spleen cells produced no cytotoxicity in the presence of pooled sera from $10^{8}$ pfu V-wt vaccinated mice. Conversely, spleen cells in the presence of pooled sera from $10^{8}$ pfu rV-neuT vaccinated mice mediated higher $\operatorname{ADCC}(\mathrm{p} \leq 0.01)$ at $1: 10$ and 1:20 dilution (38.5 and $38.25 \%$, respectively) than sera from $\mathrm{V}$-wt vaccinated mice ( 3 and $0.75 \%$, respectively).

To determine whether specific anti-Neu Igs were able to interfere with in vitro cell growth, SALTO cells were chronically treated (72 hours) with different concentrations of purified Igs from $\mathrm{rV}$-neuT or $\mathrm{V}$-wt vaccinated mice in
A
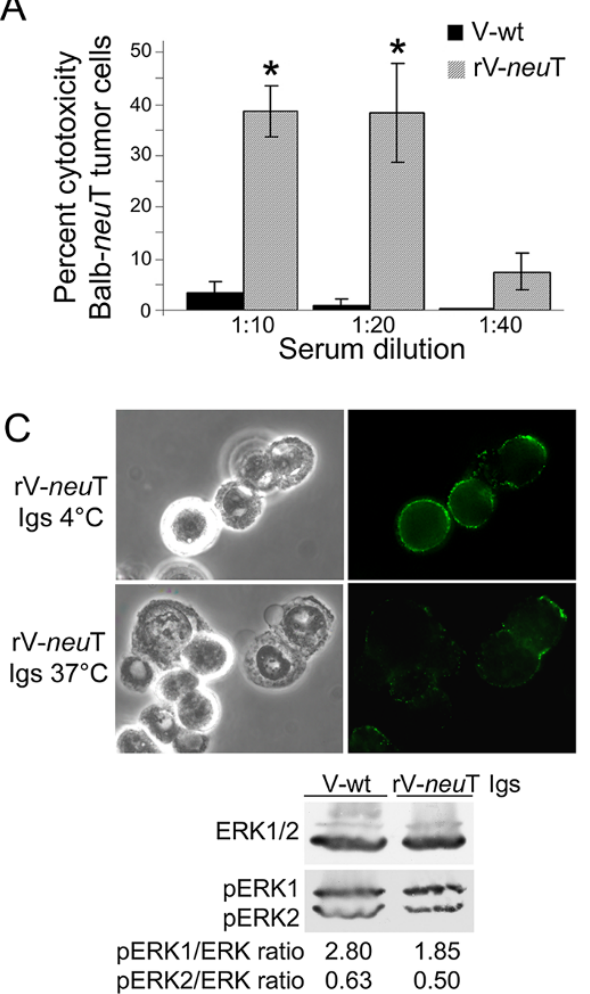
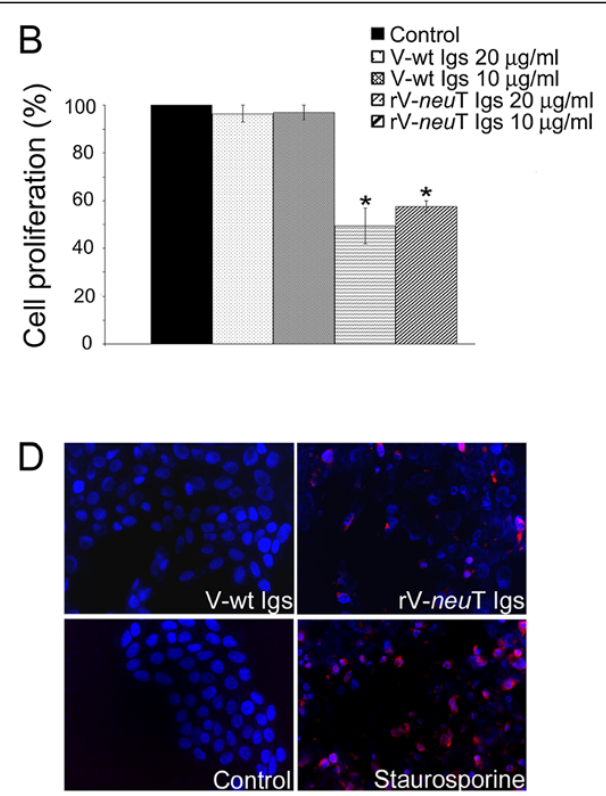

Cleaved caspase 3

Figure 4 In vitro biological activity of immune sera or purified immunoglobulins from rV-neuT vaccinated mice. Panel A: ADCC elicited by sera from $10^{8}$ pfu rV-neuT vaccinated mice. SALTO tumor cells were exposed for 2 hours to sera pooled from $r$-neuT or V-wt vaccinated mice and with mononuclear effector cells derived from normal BALB/c spleens at a ratio of 50:1. Results represent average percent cytotoxicity of two independent experiments. * $x \leq 0.01$. Panel B: Effects of anti-Neu lgs on SALTO cell proliferation. SALTO tumor cells following serum depletion were incubated in DMEM medium containing $0.2 \%$ BSA with or without rV-neuT or V-wt purified Igs. Relative cell numbers of triplicate experiments were determined after incubation of $72 \mathrm{~h}$ at $37^{\circ} \mathrm{C}$ using a sulforhodamine B based proliferation assay and expressed as percent increase or decrease in comparison to vehicle control (DMEM $0.2 \%$ BSA). ${ }^{*} p \leq 0.01$. Panel $\mathbf{C}$ : 185 Neu receptor down regulation by anti-Neu lgs. SALTO cells were stained with stained with rV-neuT purified lgs and then with goat anti-mouse lgG Alexa fluor-488-conjugated antibody. Original magnification x 500. Expression and phosphorylation of ERK1 and ERK2 after rV-neuT Igs chronically treatment of SALTO tumor cells. Serum depleted SALTO cells were treated with rV-neuT- and V-wt lgs and the ratio between ERK1 and ERK2 and pERK1/pERK2 expression was analyzed by western blotting. Densitometric ratios between the phosphorylated and total levels of each protein are reported. Panel D: Effects of anti-Neu Igs on SALTO cells apoptosis. SALTO cells were plated at $2.5 \times 10^{4}$ cells/well, incubated in DMEM medium containing $0.2 \%$ BSA with or without rV-neuT or V-wt purified lgs $(10 \mu \mathrm{g} / \mathrm{ml})$ and stained with a specific anti-cleaved caspase 3 antibody. Staurosporine $(1 \mu \mathrm{M})$ treatment was used as positive control. Nuclei were counterstained with Hoechst 33342. Original magnification x400. 
absence of fetal bovine serum. As shown in Figure 4, Panel $\mathrm{B}$, specific inhibition of cell growth was observed after treatment with Igs from rV-neuT vaccinated mice both at a concentration of 20 and $10 \mu \mathrm{g} / \mathrm{ml}$ (50.5 and $42.5 \%$ respectively, $\mathrm{p} \leq 0.01)$. Treatment with $\mathrm{V}$-wt vaccinated mice Igs was not effective on cell proliferation.

Trastuzumab, a monoclonal antibodies to p185, was shown to induce down regulation of p185 receptor on cell membrane, to block its function by hampering the formation of homodimers and heterodimers and ligand binding [42]. The ability of purified Igs from vaccinated mice to induce down regulation of p185 Neu was investigated by immunofluorescence and deconvolution analysis of immunolabeled SALTO cells. SALTO cells were stained with $\mathrm{rV}$-neuT purified Igs, then with a goat antimouse fluorescent antibody and incubated for 1 hour at $37^{\circ} \mathrm{C}$ in a $\mathrm{CO}_{2}$ incubator in complete medium. As shown in Figure 4, Panel C, Igs from rV-neuT vaccinated mice were able to induce down regulation of the p185 Neu receptor expressed on the cell surface of SALTO cells.

MAP (Mitogen Activated Protein) kinases, ERK1 and ERK2, are activated by ErbB2/Neu receptor and transduce proliferation signals. Given that chronic treatment with $10^{8}$ pfu rV-neuT Igs was able to specifically inhibit SALTO cell growth, we investigated whether phosphorylation of ERK1/ERK2 in SALTO cells was affected by $\mathrm{rV}$-neuT Igs treatment $(10 \mu \mathrm{g} / \mathrm{ml})$. V-wt purified Igs were used as control. The amount of phosphorylated ERK1 and ERK2 (pERK1 and pERK2) proteins were compared to total ERK proteins. The level of total ERK1/2 did not change after $10^{8} \mathrm{pfu} \mathrm{rV}$-neuT or $\mathrm{V}$-wt purified Igs treatment. Conversely, phosphorylation of ERK1 was significantly inhibited by $10^{8}$ pfu $\mathrm{rV}$-neuT Igs as compared to $\mathrm{V}$-wt Igs treatment (ratio 1.85 vs $2.80, \mathrm{p}=0.011$ ). pERK2 was only slightly inhibited (ratio 0.50 vs 0.63 , $\mathrm{p}=0.028$ ).

To determine whether anti-Neu Igs were able to trigger apoptosis, SALTO cells were labeled with antiactivated caspase-3 polyclonal antibody after rV-neuT or V-wt Igs $(10 \mu \mathrm{g} / \mathrm{ml})$ chronic treatment. Figure 4, Panel D shows detection of cleaved caspase-3 in SALTO cells. The fraction of apoptotic cells was determined relative to cleaved caspase- 3 positive cells. rV-neuT purified Igs induced apoptosis in 19.2\% $(\mathrm{p}<0.001)$ of SALTO cells. In comparison, treatment with V-wt Igs triggered irrelevant SALTO cells apoptosis (0.2\%). Treatment of cells with $1 \mu \mathrm{g} / \mathrm{ml}$ staurosporine resulted in $60 \%$ apoptotic cells.

Overall, our results indicate that in vitro biological activity (ADCC, inhibition of cell proliferation, down regulation of p185 Neu receptor, inhibition of ERK1/2 phosphorylation and induction of apoptosis) of $\mathrm{rV}$-neuT immune sera can provide the ability of $\mathrm{rV}$-neuT vaccinated mice of interfering with tumor growth in vivo.
T cell immune response induced by $\mathrm{rV}$-neuT vaccination

Splenocytes isolated from mice vaccinated with $\mathrm{rV}$-neuT or V-wt after the final boost, were examined for their ability to proliferate under various Neu peptides. Release of IL-2 and IFN- $\gamma$ was measured in the supernatant to assess $\mathrm{T}$ cell immunoreactivity with specific Neu epitopes. Results are reported in Table 4. All analyzed Neu peptides, except for an unrelated gag peptide, were able to specifically activate splenocytes from $\mathrm{rV}$-neuT immunized BALBneuT mice. ConA was used as positive control.

However, the extent of IL-2 and IFN- $\gamma$ release was dependent on the stimulating Neu peptide. The strongest IL-2 release was observed upon stimulation with r41 and r98 peptides which are located in the extracellular domain of rat Neu sequence. Lower IL-2 release was observed upon stimulation with r166 and r156 peptides located in the transmembrane and extracellular domains, respectively, or with r15.3 and r141 peptides. These latter are located in the extracellular domain. The strongest IFN- $\gamma$ release was detected upon stimulation with r166 and r141 peptides. High levels of IFN- $\gamma$ were also obtained upon r15.3 and r98 peptides. The $\mathrm{r} 41$ peptide, which stimulated the higher IL- 2 release, induced less IFN- $\gamma$ release. Within the different peptides, r156 stimulated the lowest IFN- $\gamma$ release.

\section{Discussion}

The incidence of head and neck carcinomas (HNC) is increasing worldwide and despite advances in their treatment, the survival rate of patients with this type of cancer has not substantially changed over the last two decades [43]. Salivary gland carcinomas are head and neck tumors of heterogeneous morphology that require typical surgical and adjuvant therapy [44]. Conservative surgery with nerve monitoring remains the state-of-the-art. Adjuvant radio(chemo)therapy is shown to increase local tumor

\section{Table $4 \mathrm{~T}$ cell immune response of BALB-neuT mice} following vaccination with $\mathrm{rV}$-neuT

\begin{tabular}{|c|c|c|c|c|c|}
\hline \multirow{2}{*}{$\begin{array}{l}\mathrm{T} \text { cell in vitro } \\
\text { stimulus }\end{array}$} & \multirow{2}{*}{$\begin{array}{l}\text { Neu peptide } \\
\text { sequence }\end{array}$} & \multicolumn{2}{|c|}{ IL-2 release* } & \multicolumn{2}{|c|}{ IFN- $\gamma$} \\
\hline & & rV-neuT & V-wt & rV-neuT & V-wt \\
\hline $\mathrm{r} 15.3$ & TYPANASL & 208 & 44 & 519 & $\leq 18$ \\
\hline $\mathrm{r} 41$ & DMVLWKDVFRKNNQL & 359 & 43 & 475 & $\leq 18$ \\
\hline r98 & IAPLRPEQLQVFETL & 343 & 44 & 510 & $\leq 18$ \\
\hline r141 & LPCHPECQPQNSSET & 209 & 43 & 555 & $\leq 18$ \\
\hline r156 & GICQPCPINCTHSCV & 265 & 45 & 365 & $\leq 18$ \\
\hline r166 & VLLFLILWWGILI & 239 & 42 & 585 & $\leq 18$ \\
\hline GAG & & 35 & 41 & 3 & $\leq 18$ \\
\hline ConA & & 1450 & 2800 & 2890 & 3150 \\
\hline
\end{tabular}

*Spleen cells from vaccinated mice were stimulated in vitro with Neu-specific peptides. IL-2 and IFN- $\gamma$ was quantitated in the supernatant $(\mathrm{pg} / \mathrm{ml})$ as a measure of T cell immunoreactivity with specific Neu epitopes. ConcanavalinA (ConA) for global T cell activation and an unrelated gag peptide served as positive and negative control, respectively. 
control, but overall survival is not automatically enhanced [44]. Thus, the development of novel therapies can supplement the pharmaceutical armamentarium presently used for the treatment of HNC and salivary gland carcinomas. A significant tumor specific overexpression of all four ErbB receptors including EGFR, ErbB2, ErbB3, and ErbB4 has been reported in head and neck squamous cell carcinomas (HNSCC) [45,46]. ErbB2 overexpression was observed in about $20 \%$ of patients with salivary duct cancer (SDC) [47], a rare high-grade aggressive tumor subtype of salivary gland carcinoma. In agreement with both EGFR and ErbB2 overexpression, cetuximab and trastuzumab, which target EGFR and ErbB2, respectively, represent important tools for treatment of salivary gland carcinomas [48]. Indeed, it was reported that a patient with SDC positive for ErbB2 had a complete objective response after combined treatment with paclitaxel, carboplatin, and trastuzumab [49]. Similarly, it was described a case of ErbB2positive metastatic submandibular SDC with a complete and durable clinical response after treatment with trastuzumab in combination with chemotherapy [50]. In addition, resolution of measurable and minimal residual disease in a patient with salivary duct cancer treated with trastuzumab, lapatinib, and bevacizumab, with treatment ongoing for more than 2 years was observed [51]. Thirteen patients with SDC and ErbB2 expression were treated with trastuzumab in adjuvant $(n=8)$ or palliative $(n=5)$ setting. It was reported that all patients with metastatic disease (5/ 5 patients) responded to treatment with trastuzumab. One patient achieved a complete response and remains with no evidence of disease 52 months after initiation of trastuzumab. The median duration of response was 18 months [52]. However, it was also reported in breast cancer patients that the objective response to trastuzumab monotherapy had a median duration of 9 months, and that the majority of responsive patients displayed resistance within 1 year [53]. Conversely, combination therapy with trastuzumab and an ErbB2/Neu T helper peptide vaccine was well tolerated and it was associated with minimal toxicity in patients with metastatic breast cancer. In addition, the combinatorial approach of the vaccine with passive immunotherapy resulted in prolonged, robust, antigenspecific immune responses in treated patients and induced epitope spreading [54]. In agreement with these evidences it is reasonable to investigate ErbB2 cancer vaccine approaches with the aim to improve the objective tumor inhibitory response in salivary gland carcinomas.

Poxvirus represents an attractive delivery vehicle of tumor antigens due to the normal post-translational modification of the inserted antigen and strong immunogenicity $[2,3,5]$. Engineered attenuated recombinant vaccinia virus encoding for tumor associated antigens has now been widely employed as a cancer vaccine in several clinical trials $[4-9,11,13,16,18,55]$. Vaccination with recombinant vaccinia virus can be achieved by systemic or local intratumoral (i.t.) injection [2,4-9,11,13,16,18].

Recently, it was demonstrated that the antitumor activity induced by i.t. vaccination with an avipox virus expressing carcinoembryonic antigen (CEA) and multiple co-stimulatory molecules was superior to that induced by systemic (subcutaneous) vaccination in CEA-transgenic mice [19]. Similarly, we recently demonstrated that local delivery of recombinant vaccinia virus encoding for neu $(\mathrm{rV}$-neuT) was superior to systemic vaccination in inhibiting the neu oncogene-mediated mammary carcinogenesis [20]. Besides, i.t. injection of recombinant attenuated Salmonella enterica serovar Typhimurium vaccine has been reported to significantly inhibit Her-2/neu-expressing tumor growth. The vaccine elicited transformation of immunosuppressive myeloid-derived suppressor cells into TNF- $\alpha$-secreting neutrophils and reduced the generation of Treg cells [56]. Similarly, i.t adenovirus (Ad) vaccination supported the generation of both Neu- and Ad-specific T effector cells [57]. Of note, it was reported that i.t. vaccination with vaccinia-expressing the tumor antigen $\mathrm{HY}$ and granulocyte macrophage colony-stimulating factor was able to overcome immunological ignorance to the tumor antigen [58]. Head and neck cancers are loco-regional diseases that appear at or close to the body surface and are easily accessible. Thus, the accessibility of salivary gland tumors allow one to envision intratumoral immunotherapy in a neoadjuvant setting.

The attempt to use intratumoral vaccination in HNC was reported by Dasgupta et al. [59]. In this study it was demonstrated that recombinant vaccinia virus expressing interleukin-2 invoked anti-tumor cellular immunity in an orthotopic murine model of HNC. However, no antigen was delivered by using this approach.

In this report, we investigated the efficacy of the rV-neuT intratumoral vaccination in hampering the growth of transplanted Neu-overexpressing salivary gland cancer cells (SALTO) in syngeneic, Neu-tolerant BALB-neuT mice. In addition, we determined whether the efficiency of vaccination was dependent on $\mathrm{rV}$-neuT doses $\left(10^{8}-10^{6} \mathrm{pfu}\right)$. Mice transgenic for the rat neu oncogene (BALB-neuT) are usually employed to evaluate the ability of ErbB2/Neu vaccines to inhibit the progression of neu-driven carcinogenesis [60]. Our observations indicated that the efficiency of vaccination was dose-dependent. Mice vaccinated with $10^{8} \mathrm{pfu}$ $\mathrm{rV}$-neuT had a mean survival time of 27 weeks while those receiving the $10^{7} \mathrm{pfu}$ and $10^{6} \mathrm{pfu} \mathrm{rV}$-neuT doses had a mean survival time of 5.25 and 9.33 weeks, respectively. rV$n e u T$ vaccination at the dose of $10^{8}$ pfu induced regression of transplanted tumors while that at $10^{6}$ e and $10^{7}$ pfu provoked a delay in the tumor growth as compared to V-wt vaccination. The risk of developing tumors in the $10^{6} \mathrm{pfu}$ and $10^{7}$ pfu rV-neuT vaccinated groups was 10.26 and 14.05 in comparison to the $10^{8} \mathrm{pfu} \mathrm{rV}$-neuT vaccinated 
group. Overall, the mean survival time of mice vaccinated with $\mathrm{rV}$-neuT, independently of the dose, was 14.8 weeks while of those receiving the $\mathrm{V}$-wt was 2.63 weeks. It is of note that $8 / 9 \mathrm{rV}$-neuT vaccinated mice were tumor free six weeks after the first vaccination and remained in this status until the $30^{\text {th }}$ week. Conversely, V-wt vaccinated mice were sacrificed for exceeded tumor volume or spontaneously died at the third week after the first vaccination.

We previously established that immune response and antitumor activity were increased by repeated $\mathrm{rV}$-neuT vaccinations. Accordingly, we performed two immunizations. One of the potential drawbacks in the use of many recombinant vaccinia immunizations in patients is that pre-existing and/or stimulated antibody and $\mathrm{T}$ cell response to vaccinia virus will preclude the spread of the administered vaccinia virus and thus decrease the expression of the inserted antigen. On the other hand, it should be noted that smallpox was eradicated worldwide more than 25 years ago; thus, young people are no longer vaccinated. In addition, recombinant avipox virus, which has a limited viral replication, can be employed to boost immune response after priming with recombinant vaccinia.

The extent of tumor growth interference in vivo was associated with high serum levels of anti-Neu antibodies, which were able to recognize p185 Neu expressed on SALTO tumor cells. $10^{8}$ pfu $\mathrm{rV}$-neuT vaccinated mice developed a significantly higher titer of anti-Neu antibodies than $10^{7}$ and $10^{6} \mathrm{pfu} \mathrm{rV}$-neuT vaccinated mice. Thus, the amount of produced anti-Neu antibodies was coincident with the efficiency of in vivo anti-tumor activity of rV$n e u T$ vaccinated mice.

Individual mechanisms including ADCC, CDC (complement dependent cytotoxicity), induction of apoptosis, or receptor down regulation have been implicated to elucidate the inhibitory effect of anti-ErbB2/Neu antibodies on the growth of cancer cells expressing ErbB2/ Neu [35,61-67]. In this study, we demonstrated that Igs from $\mathrm{rV}$-neuT vaccinated mice inhibited in vitro cell proliferation, mediated ADCC and induced apoptosis of SALTO tumor cells. Indeed, immune sera from rV-neuT vaccinated mice were able to mediate ADCC in vitro. Igs of the IgG2a isotype have been shown to mediate a more potent ADCC than other Ig isotypes in mice [68]. Anti-Neu antibodies of the IgG2a isotype are well represented in sera of $\mathrm{rV}$-neuT vaccinated mice. Purified Igs from $\mathrm{rV}$-neuT vaccinated mice were also able to induce inhibition of SALTO tumor cell growth.

Trastuzumab was shown to induce down regulation of p185 Neu receptor and to block receptor function [42]. We demonstrated that chronic treatment with purified $\mathrm{rV}$-neuT Igs were able to induce down regulation of p185 Neu receptor in SALTO cells. This biological effect can make the receptor unavailable for ligands binding thus blocking its signal transduction as we observed by revealing inhibition of the MAP kinases cascade upon rV-neuT Igs incubation of SALTO cells. Moreover, rV$n e u T$ vaccinated mice purified Igs were able to induce apoptosis of BALB-neuT tumor cells in vitro.

It has been demonstrated that cytokines and antibody production are mostly responsible for inhibition of tumor growth in BALB-neuT mice, while cytotoxic T lymphocytes might have a marginal role [35,69]. Here, we found that spleen $\mathrm{T}$ cells of $\mathrm{rV}$-neuT vaccinated mice released IFN- $\gamma$ and IL-2 upon stimulation with several Neuspecific peptides. Recognition of these epitopes in vivo potentially activates $\mathrm{T}$ cells to secrete IFN- $\gamma$ thus determining ischemic necrosis at the tumor site. Such immunodominant epitopes might boost an immune response in BALBneuT mice. Overall, our study suggests that rV-neuT i.t vaccination could be employed to induce an efficient antitumor response and reject transplanted salivary gland tumors. A Phase I study of i.t vaccine administration in men with locally recurrent or progressive prostate cancer was performed [70]. The intraprostatic administration of PSATRICOM [encoding transgenes for prostate-specific antigen (PSA) and 3 costimulatory molecules] poxviral vaccine was safe and feasible and could generate a significant immunologic response. Indeed, improved serum PSA kinetics and intense post-vaccination inflammatory infiltrates were seen in the majority of patients after vaccination [70]. Local vaccination with recombinant vaccinia virus might provide danger signals which can induce a specific immune response by alerting and activating specialized antigen presenting cells expressing costimulatory molecules and thus promoting $\mathrm{T}$ and $\mathrm{B}$ cell activation [71]. Active immunization targeting ErbB2 might block tumor growth more proficiently than passive immunotherapy thanks to the activation of a persistent memory immune response. It would also be useful in boosting a spontaneous occurring ErbB2 immune response. Moreover, an ErbB2 vaccine-based therapy might be helpful to a single anti-ErbB2 Mab therapy by concurrently inducing $\mathrm{T}$ and $\mathrm{B}$ cell immunity to several immunodominant epitopes.

Our findings may have a significant role for planning cancer vaccine protocols for the treatment of salivary gland tumors and other accessible tumors using i.t injection of recombinant vaccinia virus.

\section{Conclusions}

$\mathrm{rV}$-neuT intratumoral vaccination could be employed to induce an efficient antitumor response and reject transplanted salivary gland tumors. Our findings may have important implications in the design of cancer vaccine protocols for the treatment of salivary gland tumors and other accessible tumors using intratumoral injection of recombinant vaccinia virus. 


\author{
Abbreviations \\ ADCC: Antibody-dependent cell-mediated cytotoxicity; rV: Recombinant \\ Vaccinia; ConA: Concanavalin A.
}

\section{Competing interests}

The authors declare that they have no competing interests.

\section{Authors' contributions}

LM performed ADCC, cell proliferation, indirect immunofluorescence, immunoprecipitation and analyzed all of the results. MF carried out the statistical analysis and PCR and T cell response. MB followed the mating of mice. PS performed western blotting and analysis of apoptosis. MGG, IT, PL participated in analysis of experiments and results. FL, FC, PN, JS, AM critically revised the manuscript. $\mathrm{RB}$ conducted the antitumor animal experiments, carried out experimental design, supervised the project and wrote the manuscript. All authors read and approved the final manuscript.

\section{Acknowledgements}

This study was supported by a grant from PRIN (R.B). The authors wish to thank Barbara Bulgarini for help in manuscript preparation. We wish to thank Therion Biologics (Cambridge, MA) and Dr. G. Mazzara, which kindly provided vaccinia viruses, IRBM P. Angeletti (Pomezia, Rome) for peptides, and Dr. Eddi Di Marco (Istituto Tumori di Genova) for providing LTR-Neu cells.

\section{Author details}

'Department of Experimental Medicine, University of Rome "Sapienza", Rome, Italy. ${ }^{2}$ Department of Clinical Sciences and Translational Medicine, University of Rome "Tor Vergata", Rome, Italy. ${ }^{3}$ Internal Medicine Residency Program, University of Rome "Tor Vergata", Rome, Italy. ${ }^{4}$ Centro Studi e Ricerche Sanità e Veterinaria Esercito, Rome, Italy. ${ }^{5}$ Department of Molecular Biotechnology and Health Sciences; Molecular Biotechnology Center, University of Torino, Torino, Italy. ${ }^{6}$ Department of Experimental, Diagnostic and Specialty Medicine, University of Bologna, Bologna, Italy. ${ }^{7}$ Laboratory of Tumor Immunology and Biology, Center for Cancer Research, National Cancer Institute, National Institutes of Health, Bethesda, MD, USA.

\section{Received: 10 March 2014 Accepted: 5 May 2014}

Published: 10 May 2014

\section{References}

1. Kaufman HL: The role of poxviruses in tumor immunotherapy. Surgery 2003, 134:731-737.

2. Essajee $\mathrm{S}$, Kaufman HL: Poxvirus vaccines for cancer and HIV therapy. Expert Opin Biol Ther 2004, 4:575-588.

3. Moss B: Genetically engineered poxviruses for recombinant gene expression, vaccination, and safety. Proc Natl Acad Sci U S A 1996, 93:11341-11348.

4. Lechleider RJ, Arlen PM, Tsang KY, Steinberg SM, Yokokawa J, Cereda V, Camphausen K, Schlom J, Dahut WL, Gulley JL: Safety and immunologic response of a viral vaccine to prostate-specific antigen in combination with radiation therapy when metronomicdose interleukin 2 is used as an adjuvant. Clin Cancer Res 2008, 14:5284-5291.

5. Kaufman HL, Kim-Schulze S, Manson K, DeRaffele G, Mitcham J, Seo KS, Kim DW, Marshall J: Poxvirus-based vaccine therapy for patients with advanced pancreatic cancer. J Trans/ Med 2007, 26:60.

6. Gulley J, Chen AP, Dahut W, Arlen PM, Bastian A, Steinberg SM, Tsang K, Panicali D, Poole D, Schlom J, Michael Hamilton J: Phase I study of a vaccine using recombinant vaccinia virus expressing PSA (rVPSA) in patients with metastatic androgen-independent prostate cancer. Prostate 2002, 53:109-117.

7. Marshall JL, Hoyer RJ, Toomey MA, Faraguna K, Chang P, Richmond E, Pedicano JE, Gehan E, Peck RA, Arlen P, Tsang KY, Schlom J: Phase I study in advanced cancer patients of a diversified prime-and-boost vaccination protocol using recombinant vaccinia virus and recombinant nonreplicating avipox virus to elicit anti-carcinoembryonic antigen immune responses. J Clin Oncol 2000, 18:3964-3973.

8. Scholl SM, Balloul JM, Le Goc G, Bizouarne N, Schatz C, Kieny MP, von Mensdorff-Pouilly S, Vincent-Salomon A, Deneux L, Tartour E, Fridman W, Pouillart P, Acres B: Recombinant vaccinia virus encoding human MUC1 and IL2 as immunotherapy in patients with breast cancer. J Immunother 2000, 23:570-580.
9. Mastrangelo MJ, Maguire HC, Lattime EC: Intralesional vaccinia/GM-CSF recombinant virus in the treatment of metastatic melanoma. Adv Exp Med Biol 2000, 465:391-400.

10. Conry RM, Allen KO, Lee S, Moore SE, Shaw DR, LoBuglio AF: Human autoantibodies to carcinoembryonic antigen (CEA) induced by a vaccinia-CEA vaccine. Clin Cancer Res 2000, 6:34-41.

11. Conry RM, Khazaeli MB, Saleh MN, Allen KO, Barlow DL, Moore SE, Craig D, Arani RB, Schlom J, LoBuglio AF: Phase I trial of a recombinant vaccinia virus encoding carcinoembryonic antigen in metastatic adenocarcinoma: comparison of intradermal versus subcutaneous administration. Clin Cancer Res 1999, 5:2330-2337.

12. Izzi V, Masuelli L, Tresoldi I, Foti C, Modesti A, Bei R: Immunity and malignant mesothelioma: from mesothelial cell damage to tumor development and immune response-based therapies. Cancer Lett 2012, 322:18-34.

13. Wallack MK, Sivanandham M, Balch CM, Urist MM, Bland Kl, Murray D, Robinson WA, Flaherty L, Richards JM, Bartolucci AA, Rosen L: Surgical adjuvant active specific immunotherapy for patients with stage III melanoma: the final analysis of data from a phase III, randomized, double-blind, multicenter vaccinia melanoma oncolysate trial. J Am Coll Surg 1998, 187:69-77.

14. Kim-Schulze S, Kim HS, Wainstein A, Kim DW, Yang WC, Moroziewicz D, Mong PY, Bereta M, Taback B, Wang Q, Kaufman HL: Intrarectal vaccination with recombinant vaccinia virus expressing carcinoembronic antigen induces mucosal and systemic immunity and prevents progression of colorectal cancer. J Immunol 2008, 181:8112-8119.

15. Kaufman HL, Cohen S, Cheung K, DeRaffele G, Mitcham J, Moroziewicz D, Schlom J, Hesdorffer C: Local delivery of vaccinia virus expressing multiple costimulatory molecules for the treatment of established tumors. Hum Gene Ther 2006, 17:239-244.

16. Hörig $H$, Kaufman $H L$ : Local delivery of poxvirus vaccines for melanoma. Semin Cancer Biol 2003, 13:417-422.

17. Kaufman HL, DeRaffele G, Divito J, Hörig H, Lee D, Panicali D, Voulo M: A phase I trial of intralesional rV-Tricom vaccine in the treatment of malignant melanoma. Hum Gene Ther 2001, 12:1459-1480.

18. Gomella LG, Mastrangelo MJ, McCue PA, Maguire HC Jr, Mulholland SG, Lattime EC: Phase I study of intravescical vaccinia virus as a vector for gene therapy of bladder cancer. J Urol 2001, 166:1291-1295.

19. Kudo-Saito C, Schlom J, Hodge JW: Intratumoral vaccination and diversified subcutaneous/intratumoral vaccination with recombinant poxviruses encoding a tumor antigen and multiple costimulatory molecules. Clin Cancer Res 2004, 10:1090-1099.

20. Masuelli L, Marzocchella L, Focaccetti C, Lista F, Nardi A, Scardino A, Mattei M, Turriziani M, Modesti M, Forni G, Schlom J, Modesti A, Bei R: Local delivery of recombinant vaccinia virus encoding for neu counteracts growth of mammary tumors more efficiently than systemic delivery in neu transgenic mice. Cancer Immunol Immunother 2010, 59:1247-1258.

21. Perissinotti AJ, Lee Pierce M, Pace MB, El-Naggar A, Kies MS, Kupferman M: The role of trastuzumab in the management of salivary ductal carcinomas. Anticancer Res 2013, 33:2587-2591.

22. Pannellini T, Spadaro M, Di Carlo E, Ambrosino E, lezzi M, Amici A, Lollini PL, Forni G, Cavallo F, Musiani P: Timely DNA vaccine combined with systemic IL-12 prevents parotid carcinomas before a dominant-negative p53 makes their growth independent of HER-2/neu expression. J Immunol 2006, 176:7695-7703.

23. Diodoro MG, Di Carlo E, Zappacosta R, lezzi M, Coletti A, Modesti A, D'Antuono T, Forni G, Musiani P: Salivary carcinoma in HER-2/neu transgenic male mice: an angiogenic switch is not required for tumor onset and progression. Int J Cancer 2000, 88:329-335.

24. Di Marco E, Pierce JH, Knicley CL, Di Fiore PP: Transformation of NIH 3 T3 cells by overexpression of the normal coding sequence of the rat neu gene. Mol Cell Biol 1990, 10:3247-3252.

25. Bargmann $\mathrm{Cl}$, Hung MC, Weinberg RA: The neu oncogene encodes an epidermal growth factor receptor-related protein. Nature 1986, 319:226-230.

26. Masuelli L, Focaccetti C, Cereda V, Lista F, Vitolo D, Trono P, Gallo P, Amici A, Monaci P, Mattei M, Modesti M, Forni G, Kraus MH, Muraro R, Modesti A, Bei R: Gene-specific inhibition of breast carcinoma in BALB-neuT mice by active immunization with rat Neu or human ErbB receptors. Int J Onco/ 2007, 30:381-392.

27. Marzocchella L, Sini V, Buonomo O, Orlandi A, Masuelli L, Bonanno E, Lista F, Turriziani M, Manzari V, Roselli M, Modesti A, Bei R: Spontaneous 
immunogenicity of ribosomal P0 protein in patients with benign and malignant breast lesions and delay of mammary tumor growth in P0-vaccinated mice. Cancer Sci 2011, 102:509-515.

28. Rovero S, Amici A, Di Carlo E, Bei R, Nanni P, Quaglino E, Porcedda P, Boggio K, Smorlesi A, Lollini PL, Landuzzi L, Colombo MP, Giovarelli M, Musiani P, Forni G: DNA vaccination against rat her-2/Neu p185 more effectively inhibits carcinogenesis than transplantable carcinomas in transgenic BALB/c mice. J Immunol 2000, 165:5133-5142.

29. Bei R, Guptill V, Masuelli L, Kashmiri SV, Muraro R, Frati L, Schlom J, Kantor J: The use of a cationic liposome formulation (DOTAP) mixed with a recombinant tumor-associated antigen to induce immune responses and protective immunity in mice. J Immunother 1998, 21:159-169.

30. Bei R, Masuelli L, Moriconi E, Visco V, Moretti A, Kraus MH, Muraro R: Immune responses to all ErbB family receptors detectable in serum of cancer patients. Oncogene 1999, 18:1267-1275.

31. Masuelli $L$, Benvenuto M, Fantini M, Marzocchella L, Sacchetti $P$, Di Stefano E, Tresoldi I, Izzi V, Bernardini R, Palumbo C, Mattei M, Lista F, Galvano F, Modesti A, Bei R: Curcumin induces apoptosis in breast cancer cell lines and delays the growth of mammary tumors in neu transgenic mice. J Biol Regul Homeost Agents 2013, 27:105-119.

32. Ingrosso G, Fantini $M$, Nardi $A$, Benvenuto $M$, Sacchetti $P$, Masuelli $L$, Ponti $E$, Frajese GV, Lista F, Schillaci O, Santoni R, Modesti A, Bei R: Local radiotherapy increases the level of autoantibodies to ribosomal P0 protein but not to heat shock proteins, extracellular matrix molecules and EGFR/ErbB2 receptors in prostate cancer patients. Oncol Rep 2013, 29:1167-1174.

33. Bei R, Kantor J, Kashmiri SV, Abrams S, Schlom J: Enhanced immune responses and anti-tumor activity by baculovirus recombinant carcinoembryonic antigen (CEA) in mice primed with the recombinant vaccinia CEA. J Immunother Emphasis Tumor Immunol 1994, 16:275-282.

34. Masuelli L, Bei R, Sacchetti P, Scappaticci I, Francalanci P, Albonici L, Coletti A, Palumbo C, Minieri M, Fiaccavento R, Carotenuto F, Fantini C, Carosella L, Modesti A, Di Nardo P: Beta-catenin accumulates in intercalated disks of hypertrophic cardiomyopathic hearts. Cardiovasc Res 2003, 60:376-387.

35. Nanni P, Landuzzi L, Nicoletti G, De Giovanni C, Rossi I, Croci S, Astolfi A, lezzi M, Di Carlo E, Musiani P, Forni G, Lollini PL: Immunoprevention of mammary carcinoma in HER-2/neu transgenic mice is IFN- $\gamma$ and B cell dependent. J Immunol 2004, 173:2288-2296.

36. Sung MW, Nagashima S, Johnson JT, Van Dongen GA, Whiteside TL: The role of apoptosis in antibody-dependent cell mediated cytotoxicity against monolayer of human squamous cell carcinoma of head and neck targets. Cell Immunol 1996, 171:20-29.

37. Masuelli L, Marzocchella L, Focaccetti C, Tresoldi I, Palumbo C, Izzi V, Benvenuto M, Fantini M, Lista F, Tarantino U, Modesti A, Galvano F, Bei R: Resveratrol and diallyl disulfide enhance curcumin-induced sarcoma cell apoptosis. Front Biosci (Landmark Ed) 2012, 17:498-508.

38. Yip YL, Smith G, Koch J, Dubel S, Ward RL: Identification of epitope regions recognized by tumor inhibitory and stimulatory anti-ErbB2 monoclonal antibodies: implication for vaccine design. J Immunol 2001, 166:5271-5278.

39. Masuelli L, Budillon A, Marzocchella L, Mrozek MA, Vitolo D, Di Gennaro E, Losito S, Sale P, Longo F, Ionna F, Lista F, Muraro R, Modesti A, Bei R: Caveolin-1 overexpression is associated with simultaneous abnormal expression of the E-cadherin/ $\alpha-\beta$ catenins complex and multiple ErbB receptors and with lymph nodes metastasis in head and neck squamous cell carcinomas. J Cell Physiol 2012, 227:3344-3353.

40. Renis M, Calandra L, Scifo C, Tomasello B, Cardile V, Vanella L, Bei R, La Fauci L, Galvano F: Response of cell cycle/stress-related protein expression and DNA damage upon treatment of $\mathrm{CaCo} 2$ cells with anthocyanins. Br J Nutr 2008, 100:27-35.

41. Gallo P, Dharmapuri S, Nuzzo M, Maldini D, lezzi M, Cavallo F, Musiani P, Forni G, Monaci P: Xenogeneic immunization in mice using HER2 DNA delivered by an adenoviral vector. Int J Cancer 2005, 113:67-77.

42. Yip YL, Ward RL: Anti-ErbB-2 monoclonal antibodies and ErbB-2-directed vaccines. Cancer Immunol Immunother 2002, 50:569-587.

43. Landis SH, Murray T, Bolden S, Wingo PA: Cancer statistics, 1999. CA Cancer J Clin 1999, 49:8-31.

44. Ettl T, Schwarz-Furlan S, Gosau M, Reichert TE: Salivary gland carcinomas. Oral Maxillofac Surg 2012, 16:267-283

45. Bei R, Budillon A, Masuelli L, Cereda V, Vitolo D, Di Gennaro E, Ripavecchia V, Palumbo C, Ionna F, Losito S, Modesti A, Kraus MH, Muraro R: Frequent overexpression of multiple ErbB receptors by head and neck squamous cell carcinoma contrasts with rare antibody immunity in patients. J Pathol 2004, 204:317-325.

46. Bei R, Pompa G, Vitolo D, Moriconi E, Ciocci L, Quaranta M, Frati L, Kraus MH, Muraro R: Co-localization of multiple ErbB receptors in stratified epithelium of oral squamous cell carcinoma. J Pathol 2001, 195:343-348.

47. Clauditz TS, Reiff M, Gravert L, Gnoss A, Tsourlakis MC, Münscher A, Sauter G, Bokemeyer C, Knecht R, Wilczak W: Human epidermal growth factor receptor 2 (HER2) in salivary gland carcinomas. Pathology 2011, 43:459-464.

48. Milano A, Longo F, Basile M, laffaioli RV, Caponigro F: Recent advances in the treatment of salivary gland cancers: emphasis on molecular targeted therapy. Oral Oncol 2007, 43:729-734.

49. Kaidar-Person O, Billan S, Kuten A: Targeted therapy with trastuzumab for advanced salivary ductal carcinoma: case report and literature review. Med Oncol 2012, 29:704-706.

50. Prat A, Parera M, Reyes V, Peralta S, Cedrés S, Andreu J, Huguet $P$, del Campo JM: Successful treatment of pulmonary metastatic salivary ductal carcinoma with trastuzumab-based therapy. Head Neck 2008, 30:680-683.

51. Falchook GS, Lippman SM, Bastida CC, Kurzrock R: Human epidermal receptor 2-amplified salivary duct carcinoma: Regression with dual human epidermal receptor 2 inhibition and anti-vascular endothelial growth factor combination treatment. Head Neck 2014, 36:E25-E27.

52. Limaye SA, Posner MR, Krane JF, Fonfria M, Lorch JH, Dillon DA, Shreenivas AV, Tishler RB, Haddad RI: Trastuzumab for the treatment of salivary duct carcinoma. Oncologist 2013, 18:294-300.

53. Nahta R, Esteva FJ: Herceptin: mechanisms of action and resistance. Cancer Lett 2006, 232:123-138.

54. Disis ML, Wallace DR, Gooley TA, Dang Y, Slota M, Lu H, Coveler AL, Childs JS, Higgins DM, Fintak PA, dela Rosa C, Tietje K, Link J, Waisman J, Salazar LG: Concurrent trastuzumab and HER2/neu-specific vaccination in patients with metastatic breast cancer. J Clin Oncol 2009, 27:4685-4692.

55. Izzi V, Buler M, Masuelli L, Giganti MG, Modesti A, Bei R: Poxvirus-based vaccines for cancer immunotherapy: new insights from combined cytokines/co-stimulatory molecules delivery and "uncommon" strains. Anticancer Agents Med Chem 2014, 14:183-189.

56. Hong EH, Chang SY, Lee BR, Pyun AR, Kim JW, Kweon MN, Ko HJ: Intratumoral injection of attenuated Salmonella vaccine can induce tumor microenvironmental shift from immune suppressive to immunogenic. Vaccine 2013, 31:1377-1384.

57. Tuve S, Liu Y, Tragoolpua K, Jacobs JD, Yumul RC, Li ZY, Strauss R, Hellström KE, Disis ML, Roffler S, Lieber A: In situ adenovirus vaccination engages T effector cells against cancer. Vaccine 2009, 27:4225-4239.

58. Yang AS, Monken CE, Lattime EC: Intratumoral vaccination with vacciniaexpressed tumor antigen and granulocyte macrophage colonystimulating factor overcomes immunological ignorance to tumor antigen. Cancer Res 2003, 63:6956-6961.

59. Dasgupta S, Bhattacharya-Chatterjee M, O'Malley BW Jr, Chatterjee SK: Recombinant vaccinia virus expressing interleukin-2 invokes anti-tumor cellular immunity in an orthotopic murine model of head and neck squamous cell carcinoma. Mol Ther 2006, 13:183-193.

60. Cavallo F, Offringa R, van der Burg SH, Forni G, Melief CJ: Vaccination for treatment and prevention of cancer in animal models. Adv Immunol 2006, 90:175-213.

61. Park JM, Terabe M, Sakai Y, Munasinghe J, Forni G, Morris JC, Berzofsky JA: Early role of CD4+ Th1 cells and antibodies in HER-2 adenovirus vaccine protection against autochthonous mammary carcinomas. J Immunol 2005, 174:4228-4236

62. Dakappagari NK, Douglas DB, Triozzi PL, Stevens VC, Kaumaya PT: Prevention of mammary tumors with a chimeric HER-2 B-cell epitope peptide vaccine. Cancer Res 2000, 60:3782-3789.

63. Montgomery RB, Makary E, Schiffman K, Goodell V, Disis ML: Endogenous anti-HER2 antibodies block HER2 phosphorylation and signaling through extracellular signal regulated kinase. Cancer Res 2005, 65:650-656.

64. Brodowicz T, Kandioler D, Tomek S, Ludwig C, Rudas M, Kunstfeld R, Koestler W, Hejna M, Budinsky A, Wiltschke C, Zielinski CC: Anti-HER-2/neu antibody induces apoptosis in HER-2/neu overexpressing breast cancer cells independently from p53 status. Br J Cancer 2001, 85:1764-1770.

65. Yakes FM, Chinratanalab W, Ritter CA, King W, Seelig S, Arteaga CL: Herceptin-induced inhibition of phosphatidylinositol-3 kinase and Akt is required for antibody-mediated effects on p27, cyclin D1 and antitumor action. Cancer Res 2002, 62:4132-4141. 
66. Cuello M, Ettenberg SA, Clark AS, Keane MM, Posner RH, Nau MM, Dennis PA, Lipkowitz S: Down-regulation of the erbB-2 receptor by trastuzumab (herceptin) enhances tumor necrosis factor-related apoptosis-inducing ligand-mediated apoptosis in breast and ovarian cancer cell lines that overexpress erbB-2. Cancer Res 2001, 61:4892-4900.

67. Ye D, Mendelsohn J, Fan Z: Augmentation of a humanized anti-HER2 $\mathrm{mAb}$ 4D5 induced growth inhibition by a human mouse chimeric anti-EGF receptor mAb C225. Oncogene 1999, 18:731-738.

68. Denkers EY, Badger CC, Ledbetter JA, Bernstein ID: Influence of antibody isotype on passive serotherapy of lymphoma. J Immunol 1985, 135:2183-2186.

69. Nanni P, Nicoletti G, De Giovanni C, Landuzzi L, Di Carlo E, Cavallo F, Pupa SM, Rossi I, Colombo MP, Ricci C, Astolfi A, Musiani P, Forni G, Lollini PL: Combined allogeneic tumor cell vaccination and systemic interleukin 12 prevents mammary carcinogenesis in HER-2/neu transgenic mice. J Exp Med 2001, 194:1195-11205.

70. Gulley JL, Heery CR, Madan RA, Walter BA, Merino MJ, Dahut WL, Tsang KY, Schlom J, Pinto PA: Phase I study of intraprostatic vaccine administration in men with locally recurrent or progressive prostate cancer. Cancer Immunol Immunother 2013, 62:1521-1531.

71. Matzinger P: The danger model: a renewed sense of self. Science 2002, 296:301-305.

doi:10.1186/1479-5876-12-122

Cite this article as: Masuelli et al: Intratumoral delivery of recombinant vaccinia virus encoding for ErbB2/Neu inhibits the growth of salivary gland carcinoma cells. Journal of Translational Medicine 2014 12:122.

\section{Submit your next manuscript to BioMed Central and take full advantage of:}

- Convenient online submission

- Thorough peer review

- No space constraints or color figure charges

- Immediate publication on acceptance

- Inclusion in PubMed, CAS, Scopus and Google Scholar

- Research which is freely available for redistribution 